\title{
How a Navigation Channel Contributed to Most of the Flooding of New Orleans During Hurricane Katrina
}

\author{
Ivor Ll. van Heerden • G. Paul Kemp • Robert Bea • \\ Gary Shaffer • John Day • Chad Morris • \\ Duncan Fitzgerald • Andrew Milanes
}

Published online: 21 October 2009

(C) The Author(s) 2009. This article is published with open access at Springerlink.com

\begin{abstract}
Levee failures during Hurricane Katrina left $85 \%$ of New Orleans flooded, 1,500 dead, and about 400,000 homeless. Three separate investigations into the levee failures have been concluded, yet none of these studies conclusively determined why the St Bernard polder flooded so deeply, despite Team Louisiana's conclusion regarding early failure of the Mississippi River Gulf Outlet (MRGO) levees. Detailed wave and hydrodynamic modeling reported here reveals the cause
\end{abstract}

I. L. van Heerden $(\bowtie) \cdot$ J. Day

Louisiana State University, Baton Rouge, LA, USA

e-mail: exnatalia@aol.com

G. P. Kemp

National Audubon Society, Baton Rouge, LA, USA

R. Bea

UC- Berkeley, Berkeley, CA, USA

G. Shaffer

Southeastern Louisiana University, Hammond, LA, USA

C. Morris

CMor Consulting, Baton Rouge, LA, USA

D. Fitzgerald

Boston University, Boston, MA, USA

A. Milanes

Environmental Science Services, Inc, Baton Rouge, LA, USA 
of extensive breaching of the MRGO levees and how that created a very efficient conduit of surge water into the heart of the city.

Keywords Hurricane Katrina $\cdot$ Man-made catastrophe $\cdot$ Hydrodynamic modeling · Surge and wave impacts $\cdot$ Levee failures

\section{Introduction}

\section{Hurricane Katrina}

Hurricane Katrina made landfall in southeast Louisiana as a fast-moving Category 3 hurricane at 6:10 am on Monday 29th of August, 2005. Of the populated areas that constitute Greater New Orleans (GNO), 80\% of Orleans Parish, 99\% of St. Bernard Parish, and approximately $40 \%$ of Jefferson Parish were flooded, in some cases for weeks. This flooding cost the lives of more than 1,500 residents. Over 100,000 families were rendered homeless, the great majority of whom had heeded evacuation orders. Many observers have noted similarities between the patterns of surgeinduced flooding that occurred during Katrina and the previous storm of record, Hurricane Betsy in 1965 (van Heerden 2007). The GNO hurricane protection system (HPS) was, in fact, intended to prevent a repeat of the Betsy disaster, but this system failed during Katrina with a twenty-fold increase in loss of life.

The MRGO channel

The 76-mile MRGO project links the heart of New Orleans to the Gulf of Mexico and was approved by the U.S. Congress under the Rivers and Harbor Act of 1956 (PL 84455). The U.S. Army Corps of Engineers (USACE) began construction of this project in 1958 and completed it in 1968 at a cost of approximately $\$ 92$ million. In the process, they dredged more earth than was moved during construction of the Panama Canal and directly destroyed thousands of acres of swamps and marshes (Shaffer et al. 2009). The MRGO was authorized with a 36 foot controlling depth, 500 feet wide at the bottom and 650 feet wide at the top, with a somewhat larger cross-section (Fig. 1) across the shallow waters of Breton Sound (USACE 1999). By 2005 the channel had opened to up to 3,000 feet in some locations and had been dredged annually. Saltwater intrusion associated with the construction of the channel had killed thousands of acres of surge reducing fresh water marshes and cypress swamp.

The MRGO "Funnel"

The geography of the MRGO funnel includes the pre-existing GIWW canal along the northern margin, the enlarged portion of the GIWW referred to as MRGO Reach 1 that serves as an outlet to the IHNC; the MRGO Reach 2 channel along the south margin, and levee embankments paralleling all of the artificial channels on the inland side (Figs. 1 and 2). The funnel also contains natural features including the southern half of Lake Borgne, and thousands of acres of wetlands both on the inboard and outboard sides of the hurricane protection structures. Lake 
Fig. 1 Graphic created by the New Orleans Time-Picayune newspaper to explain the role of the MRGO funnel in the flooding of New Orleans during Hurricane Katrina

\section{STORM SURGE DURING HURRICANE KATRINA}

Much of the area's flooding from Katrina resulted from storm surge that rocketed through a narrow "funnel" created where the Mississippi RiverGulf Outlet (MR-GO) joins the Intracoastal Waterway (GIWW).

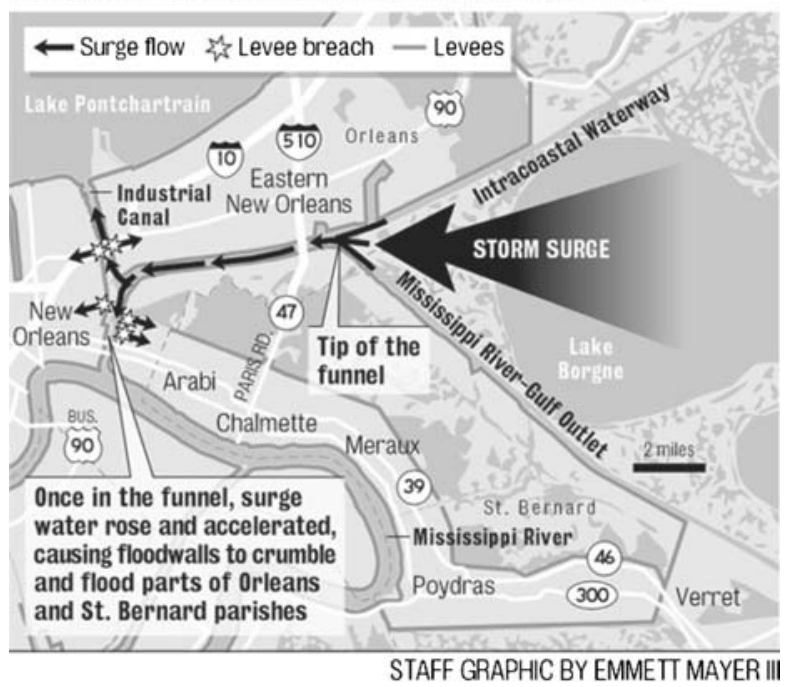

Borgne, a very large shallow bay elongated along a southwest to northeast axis, providing more than 40 miles of open water in this direction-a very long "fetch" over which hurricane winds can build surge and waves (Fig. 1). The inboard swatch of tidal marsh, the nearly 32,000 acre Central Wetlands Unit (CWU) is located between the main federal levees along the south bank of the MRGO and a

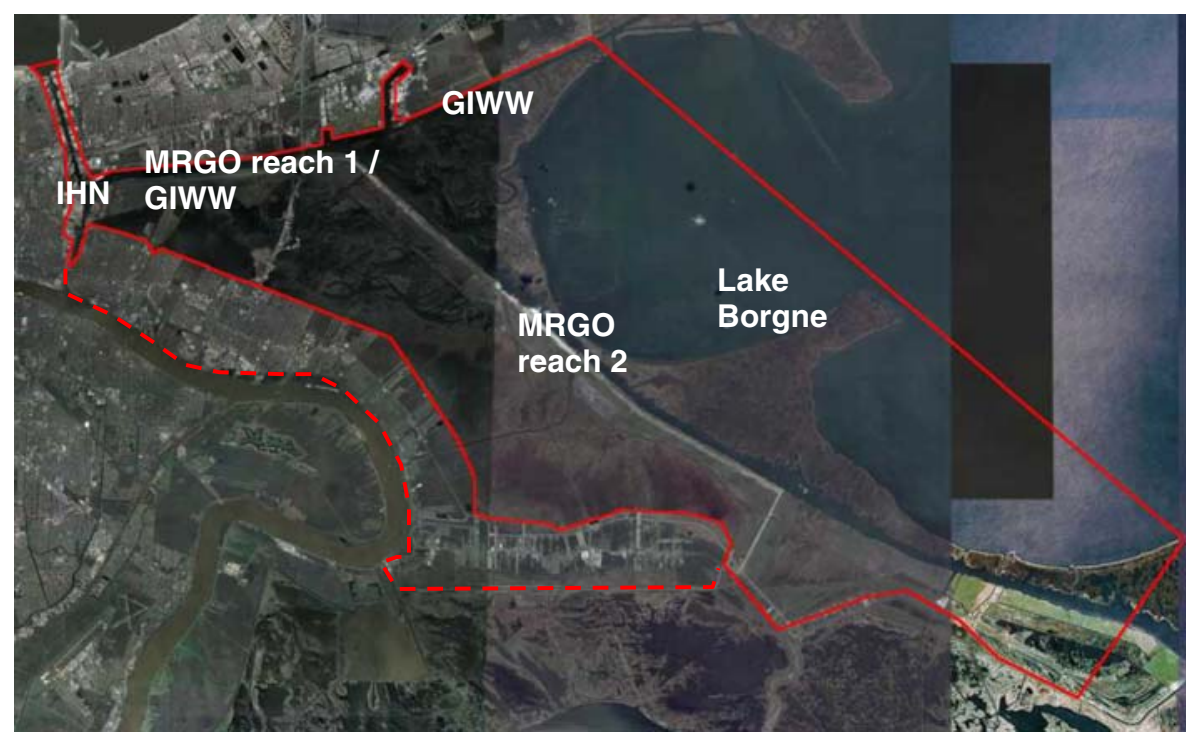

Fig. 2 FINEL model computational domain outlined in solid line. Urban area bounded on west with dashed line 
lower state-built levee known as the 40 Arpent Levee (Fitzgerald et al. 2008). Three drained and developed polders surround the Lake Borgne funnel, including New Orleans East to the north, the Orleans Metro area to the west, and the combined Lower 9th Ward and St. Bernard Parish neighborhoods to the south. The developed and drained portion of the St. Bernard polder lies south of the 40 Arpent Levee. All of these developed polders received floodwaters from the MRGO channel and funnel.

The CWU used to be dominated by 2.4 to 3.0 miles of fresh water bald cypress (Taxodium distichum) — water tupelo (Nyssa aquatica) swamp that have become intermediate to salt marshes and open water ponds since the construction of the MRGO (Fitzgerald et al. 2008). Pump stations located along the 40 Arpent levee discharge storm drainage into these wetlands and this limited freshwater introduction has preserved a few stands of the once more extensive swamp forest that covered this area prior to construction of the MRGO (Fitzgerald et al. 2008). St. Bernard has some of the highest land on the East Bank of New Orleans, following as it does the natural levee of the Mississippi River and some of its abandoned distributaries (Fig. 1). Despite being relatively high by local standards, the St. Bernard polder experienced the most violent, spatially expansive and deepest flooding in the entire metro area during the Katrina event (Fig. 3). Except for a limited contribution from rainfall, all flooding of the St. Bernard polder was caused by water that passed through or across one or more reaches of the MRGO. This water entered the developed area as a result of catastrophic floodwall failures along the IHNC on the western margin, by overtopping of levees on MRGO Reach 1, and by flow through breaches in the federally built levees along the MRGO Reach 2. The interior 40 Arpent Levee was protected by over two miles of the Central Wetlands Unit and was relatively undamaged, but it averaged only 6.5 feet high and was completely overtopped when floodwaters from the MRGO filled the Central Wetlands Unit beyond this level.

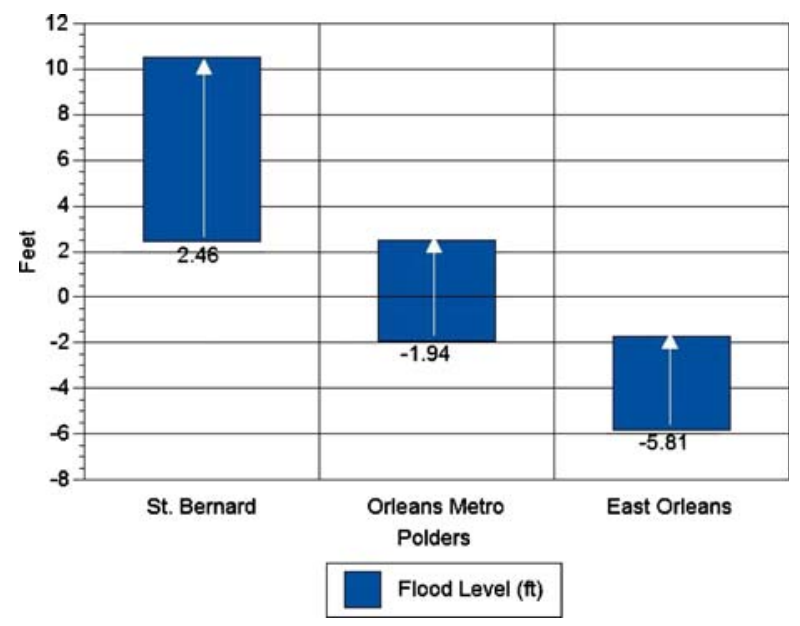

Fig. 3 Comparison of mean maximum floodwater elevation with average elevation of flooded land in three New Orleans polders (van Heerden et al. 2007) 
Study objectives

The research described herein was undertaken to develop a greater understanding of the MRGO levee failure mechanisms and a detailed interpretation of the conveyance contribution of the MRGO to flooding. Additionally, the study compared the Katrina levee failures and associated flooding to a hypothetical scenario in which there was no MRGO channel and associated wetland loss; a "Neutral MRGO." The "Neutral MRGO" analyses are based on the rationale that the USACE had a Congressionally directed responsibility to manage the MRGO navigation project so that it caused no added, unmitigated impact on the ability of the hurricane protection project to also fulfill its mission - also Congressionally mandated - to protect the City of New Orleans and St. Bernard Parish from hurricane-induced flooding.

\section{Computer models used to reconstruct surge and waves}

In order to fully understand the Katrina hydrodynamics, reliance on computer models to reconstruct the surge and wave dynamics that were in play during the passage of this storm, is essential.

ADCIRC storm surge model

The S08 version of ADCIRC (described in detail in van Heerden and Bryan 2006) was used primarily to provide boundary conditions for the FINEL hydrodynamic model (Fig. 2).

FINEL hydrodynamic model

The numerical model FINEL is a two-dimensional, depth averaged, hydrodynamic model running on an unstructured grid using the finite element method and was developed by Svašek Hydraulics and the Fluid Mechanics Section of the Civil Engineering faculty of TUDelft (de Wit et al. 2008). This model was set up with far more detail in the bathymetry and topography than has been available to date in any ADCIRC version in part to better study the effects of bottom friction differences between open water and various wetland types. Bays and channels tend to provide less resistance to flow than do marshes and particularly swamp wetlands. FINEL provides the flexibility necessary to examine incrementally the effects of adding, removing, or modifying channels, wetlands and flood protection elements within the landscape to gain a greater understanding of how each contributed to surge dynamics (Fig. 2). It should be noted that because of time constraints, the FINEL model domain does not include the New Orleans East and Orleans Metro polders, and therefore does not directly simulate overtopping into these regions (de Wit et al. 2008). While it faithfully replicates surveyed overbank, floodwall and levee elevations as they existed prior to Katrina along the north bank of GIWW/MRGO Reach 1 and the IHNC, it also does not consider the effects of breaches that occurred during that storm in the southern portion of the IHNC between the MRGO junction and the lock (Fig. 1). This means that it is expected to 
over-predict surge elevations actually observed in the southern part of the IHNC, and, consequently, overtopping into the Lower 9th Ward and Central Wetlands Unit just to the north. These limitations were addressed by added analyses of overtopping potential, using a 1D weir model for the polders not explicitly included in the model domain (de Wit et al. 2008).

\section{SWAN wave model}

The SWAN wave model is a third-generation wave model and represents the current state of the art for wave simulation. Svašek Hydraulics and TUDelft were involved in its development and were particularly qualified to simulate the wave climate along MRGO Reach 2 during Katrina (Gautier et al. 2008). SWAN uses a grid to compute how waves generate, dissipate and propagate under the influence of wind, bathymetry, vegetation type, water levels, currents and incoming waves (Fig. 4). This is a finite-difference model built, unlike ADCIRC or FINEL, of equal-sized rectilinear cells, that achieves greater resolution through the use of nested grids, in which larger grids provide boundary conditions for smaller ones. We applied SWAN to study the Katrina storm scenarios with and without the MRGO project, and with and without the marshes and swamps that it destroyed (Gautier et al. 2008). As is true for the steady and unsteady flows that contribute to surge, vegetation type profoundly affects the rate of wave energy dissipation that ultimately determines the size and character of the waves that attack man-made structures like the levees. The SWAN model is well set up to investigate such interactions, including the unique attributes of a wetland swamp canopy to separate the winds that build waves from the water surface, leading to a more rapid loss of wave height and energy than can be attributed to bottom friction effects (Gautier et al. 2008).

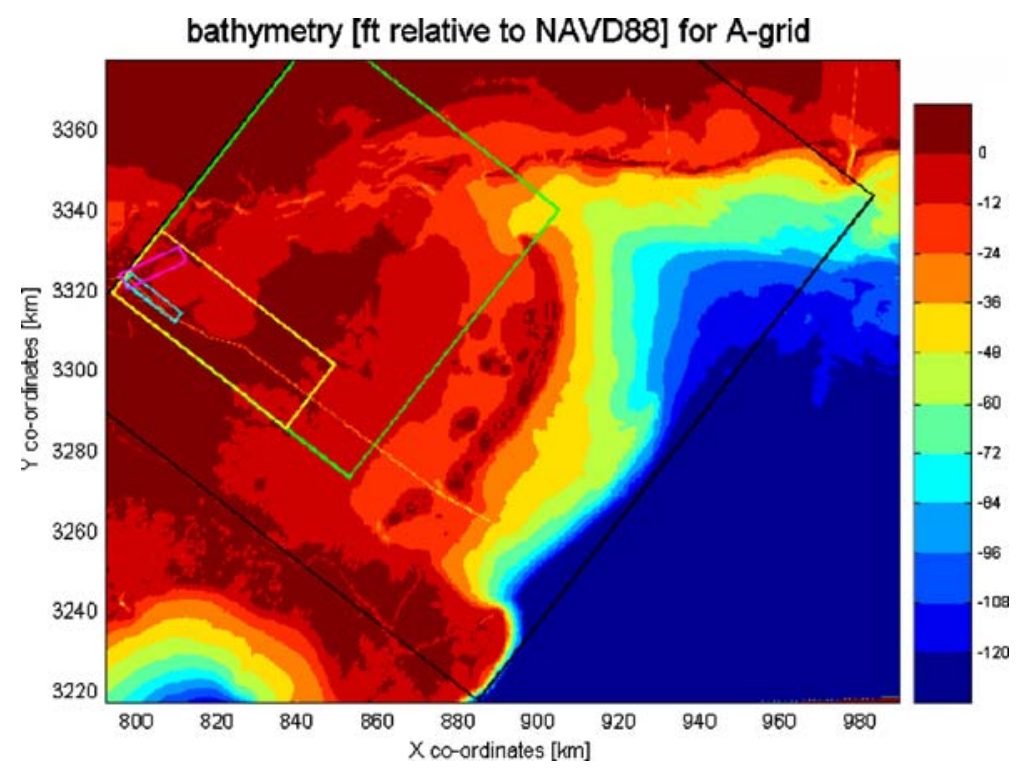

Fig. 4 SWAN Nested Grids A-G positioned over bathymetry and topography 


\section{Analytical approach}

\section{Influence of vegetation}

The effect of even low-lying marsh vegetation to retard and attenuate storm surge also has been known for as long as the MRGO has existed and was, in fact, one criterion for the original Chalmette levee design (USACE 1963; USACE 1967). One of the major adverse impacts of the MRGO project was to change marshes to open water and swamp to marshes (Fitzgerald et al. 2008; Shaffer et al. 2009). Accordingly, it has been very important to incorporate the effects of these MRGOinduced changes on surge and wave dynamics experienced during Hurricane Katrina, and then to assess whether the presence or absence of swamp and marsh affected the timing and severity of flooding of populated areas.

\section{Scenarios modeled}

Two different scenarios were modeled. Scenario 1-“MRGO As-Is" modeled the actual Katrina storm conditions as accurately as possible (Table 1). To assess the impacts of the MRGO channel; how it exacerbated surge conveyance and the wind wave field facing the Reach 2 levees, a hypothetical Scenario 2C - a "no MRGO" setting with 1958 wetlands intact also was modeled. This scenario can be considered a "Neutral" MRGO setting. The MRGO Reach 2 Channel was modeled in two configurations (Table 1). The greatly expanded channel 2,000 to 3,000 feet wide and more than 40 feet deep that existed in front of the Reach 2 levees before Katrina occurs only in Scenario 1; this channel reach is completely absent in Scenario 2C. The MRGO Reach 1 Channel was also modeled in two configurations (Table 1). The 1,000 foot wide channel that provided the outlet from the funnel to the IHNC during Katrina occurs only in Scenario 1 and is reduced to the pre-MRGO dimensions of the antecedent GIWW barge channel in Scenario $2 \mathrm{C}$, about $10 \%$ of its current cross-section.

A merger of ADCIRC output and high water mark data was used to provide boundary conditions for FINEL, as we sought a higher level of accuracy than could be obtained from any of the ADCIRC versions now in use (Gautier et al. 2008). FINEL was then calibrated to provide benchmark surge hydrographs at specific read-

Table 1 Katrina Simulation Scenarios for characterization of MRGO Reach 1 and Reach 2 surge, current, and wave characteristics

\begin{tabular}{lllllll}
\hline Scenario & MRGO & $\begin{array}{l}\text { MRGO/ } \\
\text { GIWW }\end{array}$ & $\begin{array}{l}\text { Reach 2 } \\
\text { Levees }\end{array}$ & $\begin{array}{l}\text { Reach 1 } \\
\text { Levees }\end{array}$ & $\begin{array}{l}\text { 40 Arpent } \\
\text { Levee }\end{array}$ & Vegetation \\
& $\begin{array}{l}\text { Reach 2 } \\
\text { channel }\end{array}$ & $\begin{array}{l}\text { Reach 1 } \\
\text { channel }\end{array}$ & & & & \\
& Existing & Existing & Existing & Existing & Existing & Existing \\
1 & $8 / 2005$ & $8 / 2005$ & $8 / 2005$ & $8 / 2005$ & $8 / 2005$ & $8 / 2005$ \\
2 C Neutral & None & Pre MRGO & $\begin{array}{r}\text { Existing } \\
8 / 2005\end{array}$ & $\begin{array}{r}\text { Existing } \\
8 / 2005\end{array}$ & $\begin{array}{r}\text { Existing } \\
8 / 2005\end{array}$ & $\begin{array}{c}\text { Pre MRGO } \\
1958\end{array}$ \\
\hline
\end{tabular}


out locations (Fig. 5). FINEL was also used to generate a surge surface at hourly intervals beginning at 0400 on the morning of August 29, 2005. SWAN was then run over the surge surface generated by FINEL to provide hourly snapshots of wave characteristics (Fig. 6).

\section{The MRGO funnel and its effect on surge}

FINEL analysis of funnel effects

\section{Scenario 1 or Katrina-As-Is}

FINEL predicts that the maximum surge is transmitted through MRGO Reach 1 with little decrease to the south end of the IHNC. Overtopping of flood protection structures occurs where the surge is highest south of Lake Borgne, and where levee and floodwall crowns are lowest, along MRGO Reach 1 and at the southern end of the IHNC. But because the structures do not breach in the model, the Central Wetlands Unit storage area is not filled by the end of the sequence (Fig. 7). Under the modeled conditions for the flood protection structures, flooding of developed areas of the St. Bernard polder through overtopping of the 6.5 foot 40 Arpent Levee would not have occurred except at the western margin into the Lower 9th Ward. There, overtopping would have lasted less than $3 \mathrm{~h}$, and would have been less than $2 \mathrm{~h}$ on the MRGO levees south of Lake Borgne.

What is most apparent in the velocity plots is that the larger dimensions of the channels constructed or enlarged as part of the MRGO project are carrying a disproportional share

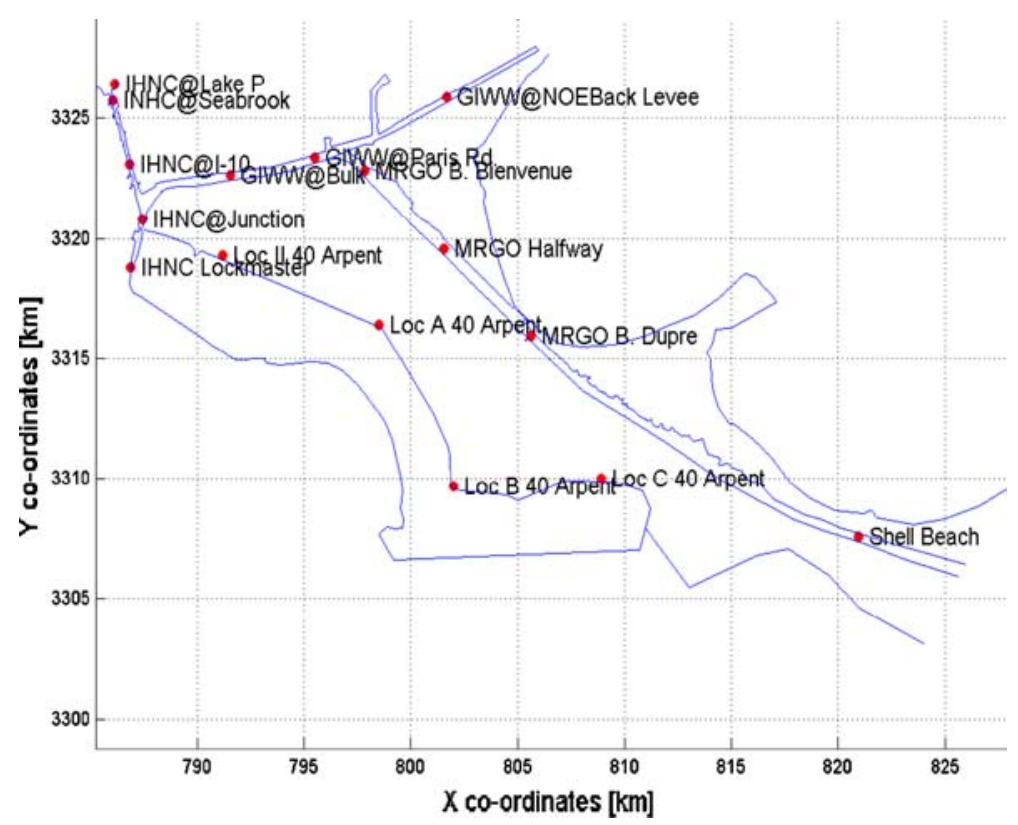

Fig. 5 Locations for FINEL time-series output of water level, current direction and velocity 

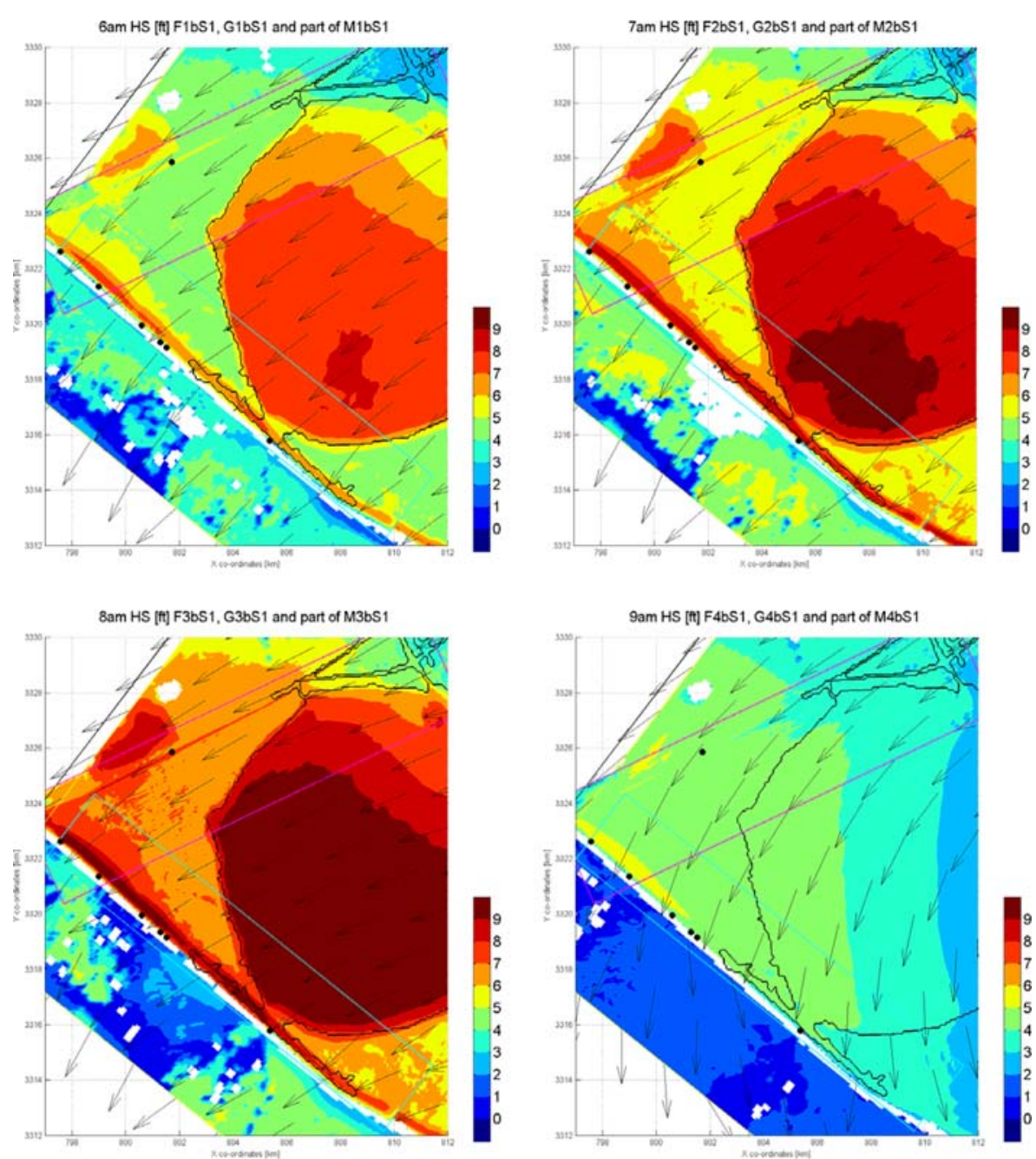

Fig. 6 Evolution of significant wave heights (feet) in eastern lobe of Lake Borgne predicted by SWAN from 0600 (top left), 0700 (top right), 0800 (bottom left) and 0900 (bottom right) (Gautier et al. 2008)

of flow. The channel from about Bayou Bienvenue all the way into the IHNC looks like a major river in the velocity maps (Fig. 7). It can be seen that velocities in MRGO Reach 1 are only slightly higher than in Reach 2 between the Bayou Bienvenue control structure and the turn at the junction with the GIWW. This suggests that the vast majority of flow entering Reach 1 is coming from Reach 2 (Fig. 7), and that this flow is being efficiently conveyed by the Reach 1 channel all the way into the IHNC.

\section{Neutral MRGO Scenario 2C}

In this scenario surge along the shores of Lake Borgne is simulated to be representative of the conditions before the construction of the MRGO, conditions 


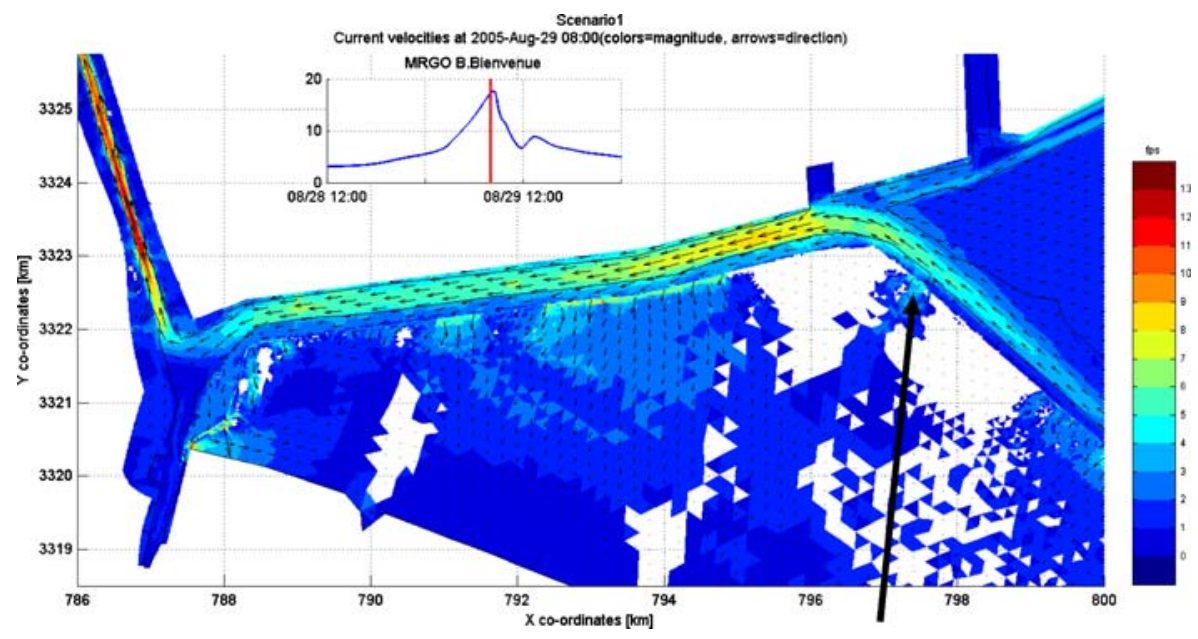

Fig. 7 Flow velocities and direction in MRGO Reaches 1, 2 and IHNC at 0800 for Katrina-As-Is scenario, showing overtopping across south levee of MRGO Reach 1. Maximum velocities in Reach 1 and IHNC are 8 and 11 feet per second (fps on scale), respectively (de Wit et al. 2008). Arrow indicates Bayou Bienvenue

that essentially would have persisted to the present if there had been no channel (Shaffer et al. 2009). Surge hydrographs were prepared at the same output locations as shown for the earlier scenarios, but also at additional points along the 40 Arpent Levee (Fig. 5). The replacement of the MRGO channel by marsh had a minor effect on the surge hydrographs at locations along the MRGO levee alignment toward the east side of the funnel, but a progressive lowering of the peak surge and a time-lag becomes more prominent at locations farther west (Fig. 8). This is particularly true for the locations inside the GIWW and IHNC so that at the lock on the south side of the IHNC the surge is about 3.0 feet lower than for the Katrina-As-Is condition. The answer is that the apparently minor increases in peak surge elevation and duration that the ADCIRC and FINEL models allow us to attribute to the MRGO project have a disproportionate impact on overtopping caused flooding across the adjacent levee structures because in many places the crown elevations are not much lower than the surge elevation. Because the length of these structures extend for several miles, even a minor increase in the overtopping rate per linear foot results in much larger volumes of water overtopping the structure.

\section{MRGO channel reach discharge analysis}

To further understand surge behavior in a funnel situation (de Wit et al. 2008), discharge estimates were developed at cross-sections laid across the MRGO Reach 1 and Reach 2 channels (Fig. 9). The cross-sectional area for each of these traverses with an assumed +16 foot (NAVD88) water elevation is given in Table 2, and the discharges for each cross-section and each scenario is provided at hourly intervals in Table 3. The Scenario $2 \mathrm{C}$ cross-section of Reach 1 is roughly half that of the Katrina-As-Is section because about half of the total cross-sectional area of Reach 1 for Scenario 1 is above the overbank when the water level is at +16 feet (Table 2). 


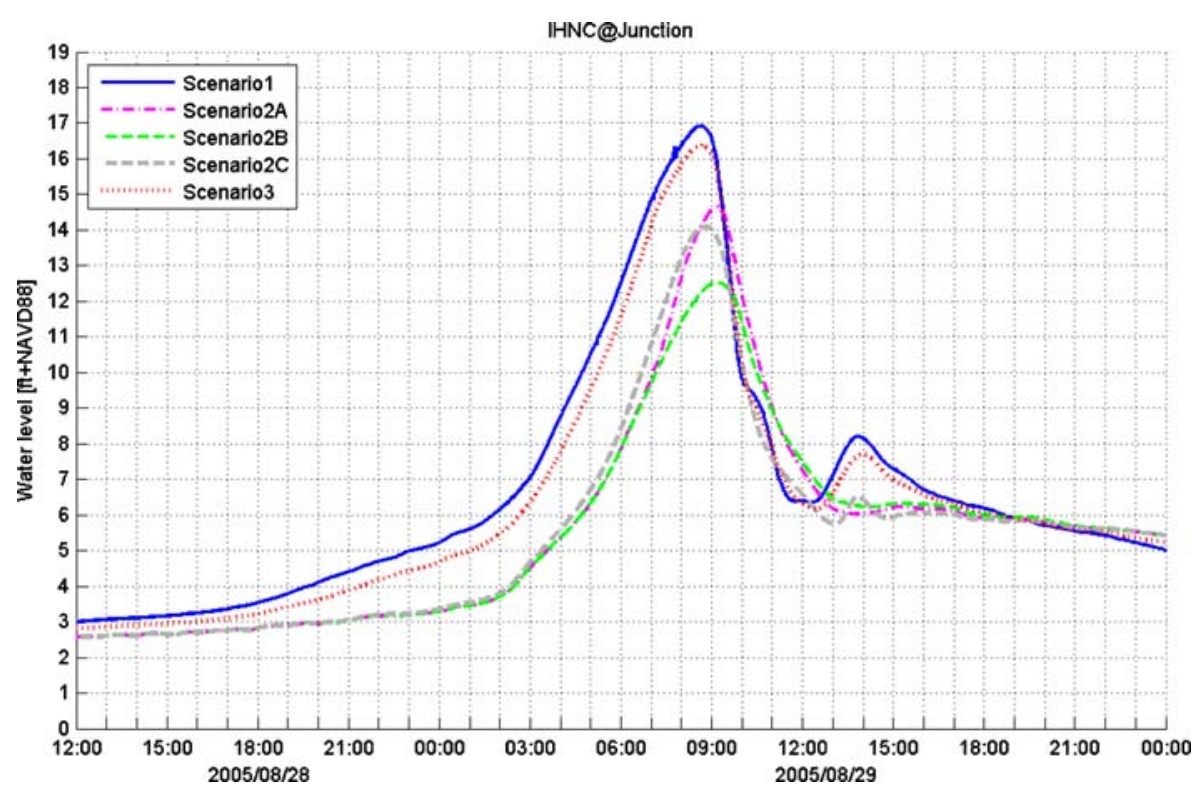

Fig. 8 FINEL generated Katrina hydrographs for test scenarios (de Wit et al. 2008). Scenario 2C, the grey dashed line is of interest and is lower than the Katrina-As-Is run, scenario 1, at this location (Fig. 5), with a pronounced lag and much shorter duration

These discharges are very large, ranging for MRGO Reach 1 in the Katrina-As-Is scenario from 173,000 to 430,000 cfs over the course of five hours (Table 3). The Reach 1 channel entrains water in addition to that contributed by Reach 2 from the GIWW channel and from across the remaining wetlands. This added water becomes more significant at the 0800 surge peak. At peak surge, the volume contributed from outside of Reach 2 rises from about 25 to $40 \%$ and continues to increase to $70 \%$ at 0900 as the discharge in Reach 2 drops precipitously when the wind shifts.

As might be expected, discharge through the Reach 1 section is greatly diminished when the ship channel is removed as is the case in Scenario 2C. Flow then is largely overland even if it is constrained by levees or berms, as under scenario 2C. Peak discharge for this scenario in Reach 1 is only slightly more than a third of the Katrina-As-Is discharge (Table 3). The Reach 2 discharge across the unbroken marsh at the Bayou Bienvenue cross-section is less than $20 \%$ of its value when the fully enlarged channel section is available. The direction of flow reverses

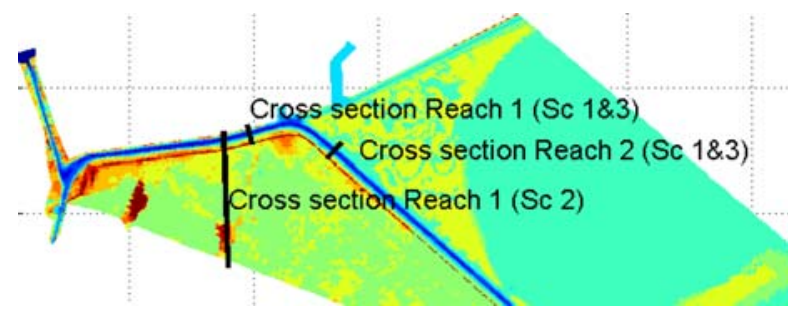

Fig. 9 Cross-sections for which surge discharge was calculated using FINEL (de Wit et al. 2008 expert report) 
Table 2 Cross-sectional area for each traverse in Fig. 9 at a uniform elevation of +16 feet (NAVD88) from de Wit et al. 2008 expert report appendix

Cross-sectional area $\left(\mathrm{ft}^{2}\right)$

Scenario 1

Scenario $2 \mathrm{C}$

\section{MRGO Reach 1}

MRGO Reach 2

MRGO Reach 1

MRGO Reach 2
67,000

75,000

38,000

36,000

to the east at this location by 0900 as the winds shift. When a channel is absent in Reach 2, there is little reason to think that this cross-section should contribute much more flow to Reach 1 than any other marsh traverse of similar length, but it does, roughly $30 \%$, at least until the winds shift. This occurs in all likelihood because as the surge piles up on the MRGO levees along the south margin of the funnel, flow is deflected preferentially along the levee face toward the entrance to Reach 1 . Because the water is incompressible and cannot escape, changes made to the geometry in one place propagate throughout the system either as surge elevation increases or decreases, or as delays in surge rise or fall.

\section{Levee overtopping analysis}

Locations were selected for calculation of structure overtopping using the FINEL surge output as the upstream input and considering the surveyed elevation of the structure crown in the pre-Katrina condition (Fig. 10). Knowing the elevation difference between the water level in FINEL and the levee crest, a time line of the overtopping rate can be calculated for each selected location (Figs. 11 and 12). The Orleans Metro and New Orleans East polders are not included in the model grid so overtopping into those bowls, as well as breaching, do not occur in the FINEL model. So the FINEL hydrographs in the IHNC and MRGO Reach 1 will be a little higher than what actually would occur in each scenario, as was discussed in the calibration section (de Wit et al. 2008). Overtopping rates in the MRGO Reach 1 and to a greater degree in the IHNC must therefore be considered an upper bound. The surge peak on structures within Lake Borgne will be more realistic estimates when no breaching occurs, because the surge in Lake Borgne is unaffected by overtopping (de Wit et al. 2008).

Table 3 Discharge to the west across the test cross-sections in cubic feet per second (cfs) predicted by FINEL for scenarios 1 and 2C at hourly intervals for Katrina surge (de Wit et al. 2008)

\begin{tabular}{llrrrrrr}
\hline & $4: 00 \mathrm{am}$ & $5: 00 \mathrm{am}$ & $6: 00 \mathrm{am}$ & $7: 00$ am & $8: 00$ am & 9:00 am \\
\hline Scenario 1 & MRGO Reach 1 & 173,000 & 202,000 & 236,000 & 293,000 & 430,000 & 234,000 \\
& MRGO Reach 2 & 149,000 & 161,000 & 179,000 & 211,000 & 264,000 & 72,000 \\
\multirow{2}{*}{ Scenario 2C } & MRGO Reach 1 & 44,000 & 63,000 & 86,000 & 117,000 & 157,000 & 114,000 \\
& MRGO Reach 2 & 14,000 & 20,000 & 28,000 & 39,000 & 48,000 & $-4,000$ \\
\hline
\end{tabular}




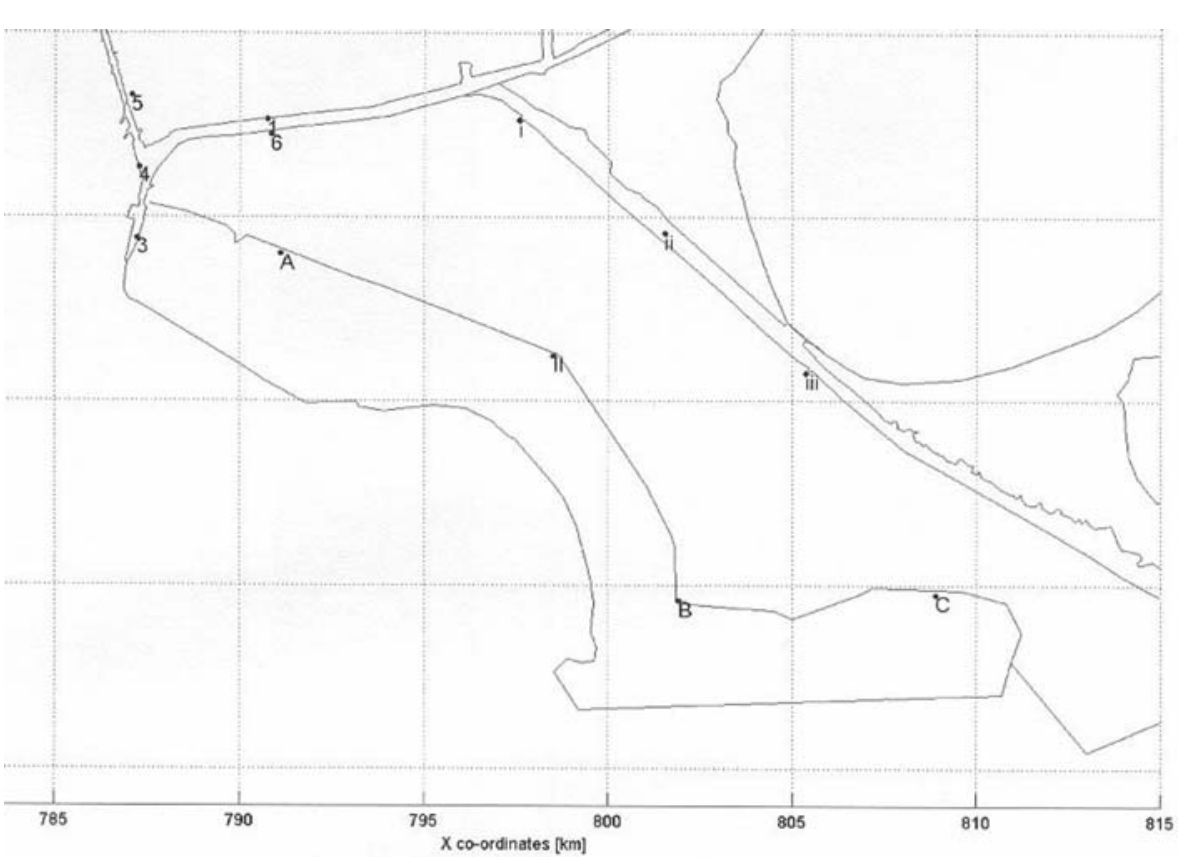

Fig. 10 Output locations for overtopping volume analysis (de Wit et al. 2008)

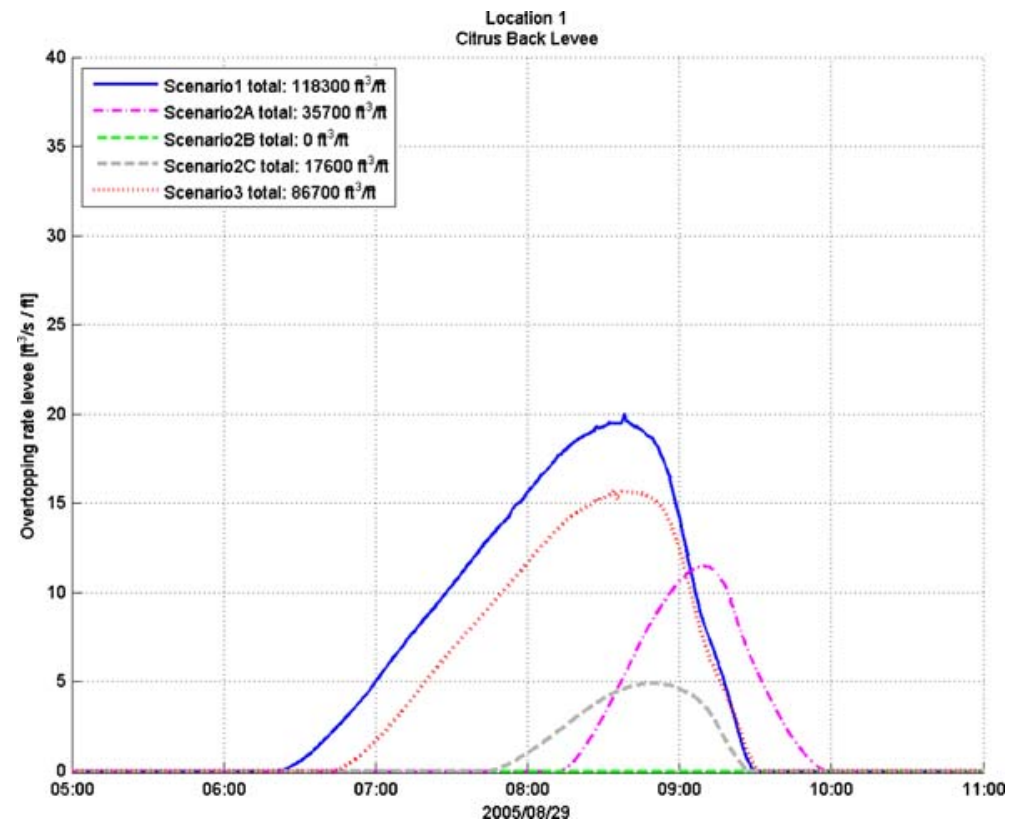

Fig. 11 Overtopping rates calculated for test scenarios at the Citrus Back Levee (de Wit et al. 2008). See Fig. 10 for location 

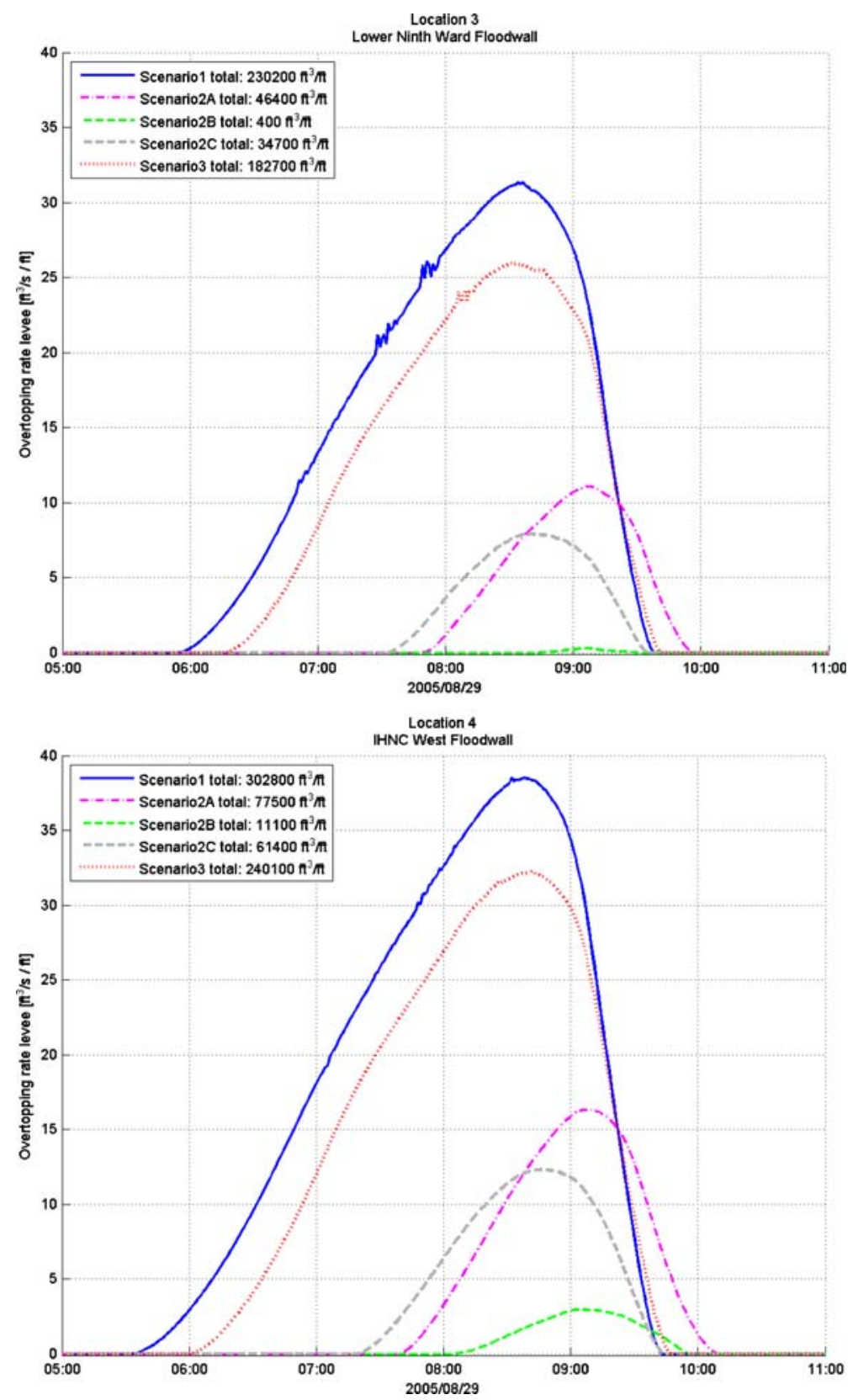

Fig. 12 Overtopping rates calculated for Scenarios 1 and $2 \mathrm{C}$ at location 3 on the Lower 9th Ward floodwall (top) and location 4 on the IHNC West floodwall (de Wit et al. 2008)

While we know that FINEL is over predicting surge in the IHNC and to a lesser degree in MRGO Reach 1, and that this results in higher overtopping rates over the structures along these channels, this is true across the board for all scenarios. The point by point comparison acts to normalize these effects, rendering the 
comparisons meaningful. The first observation is that the Katrina-As-Is scenario caused more overtopping at all locations where common points could be compared. The best overall performance was achieved in Scenario 2C by returning the landscape to its pre-MRGO condition, but with the MRGO hurricane protection levees in place as they were before Katrina. This resulted in a fairly uniform reduction in overtopping volume of 80 to $85 \%$ at points discharging into all three of the developed polders. Comparison of Scenarios 1 and $2 \mathrm{C}$ showed that enlargement of the GIWW to create MRGO Reach 1 provided a much greater potential for conveyance of Lake Borgne surge into New Orleans particularly after the cypress forests were destroyed.

The Reach 2 channel posed less of a problem, however, for enhancing storm surge than Reach 1 until, the surge funnel geometry was worsened by construction of the levees along the its south bank. First, the levees took 'offline' the significant amount of storage afforded by the 32,000 acre Central Wetlands Unit. Second, the levee project introduced a new and very dangerous dynamic in the hydraulic feedback between the ship channel and the adjacent berms. After the hurricane protection was constructed surge could then build up on the slopes of the MRGO levees and drive added flow through the adjacent deep channel toward Reach 1, an interaction that would not have occurred if one or the other of these projects had not been built in the close conjunction that they were. In the 'Neutral MRGO' condition the surge elevation was reduced slightly and the rise was delayed almost everywhere around the margins of the funnel, but more so toward the west. Even slight reductions in peak surge elevation or delays in peak onset could combine to significantly reduce overtopping of the levee flood protection structures throughout the funnel (Fig. 12). When both reaches of the MRGO were removed, overtopping was reduced by about $80 \%$ for all of the three developed polders that experienced catastrophic flood damage on August 29, 2005.
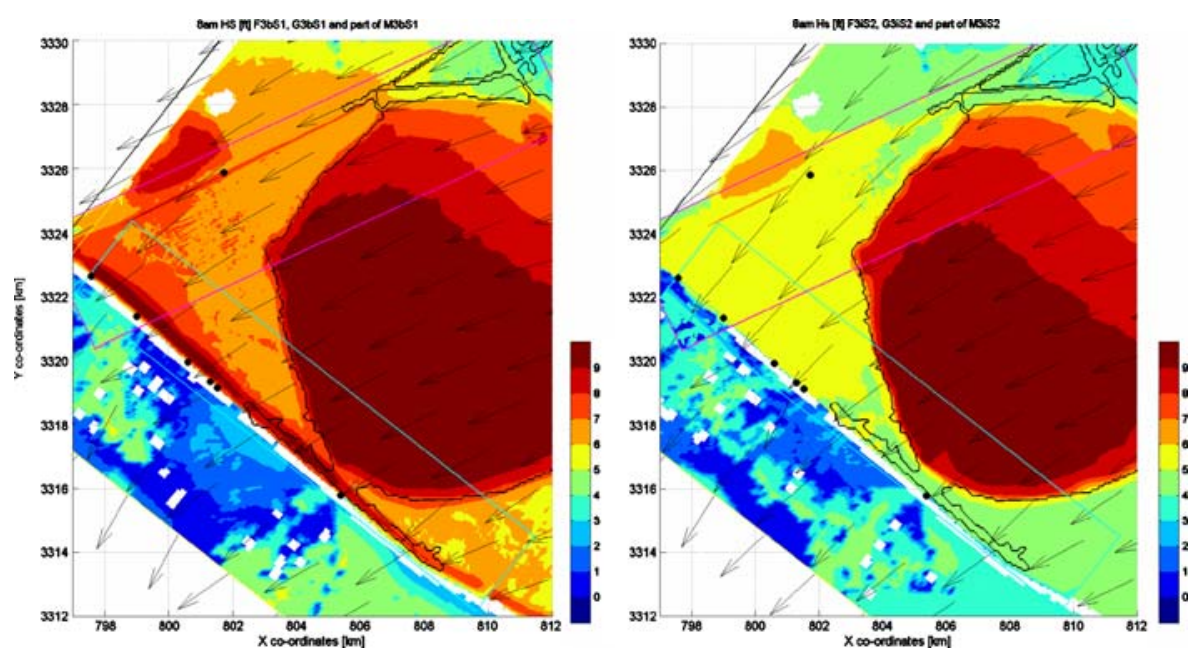

Fig. 13 Scenario 1 and Scenario $2 \mathrm{C}$ SWAN results $\mathrm{Hs}[\mathrm{ft}]$ and wave direction, 8:00 am LT. Note how the waves in the MRGO channel are almost twice as high in Scenario 1 as compared to Scenario $2 \mathrm{C}$ 


\section{Effects of MRGO reach 2 on waves}

Wind speeds over the Lake Borgne-Chandeleur Sound complex ranged up to a maximum of about 90 knots. The prevailing wind direction over Lake Borgne was from the northeast, almost perfectly aligned with the long axis of the Lake from 04:00 to 09:00 on the morning of August 29, 2005 (Gautier et al. 2008). The Scenario 1 Katrina data show that significant wave heights build in the channel up to a maximum of about 9 feet along the whole of Reach 2 in front of the levees (Fig. 6). Significant wave heights drop appreciably as the surge maximum passes, as can be seen in the 09:00 image (Fig. 6). The growth of the waves as they cross the 2,000 to 3,000 foot wide channel is apparent.

Figure 13 shows the peak wave heights for both Scenarios 1 and $2 \mathrm{C}$. What is very evident is that the very wide MRGO channel at the time Katrina hit amplified the waves from a maximum of 5.5 feet with no channel to 9.2 feet with the channel. This is what made the difference for these fragile structures, and for the early onset of the flooding in St. Bernard. This characteristic of the MRGO channel of wave amplification was not considered in the design of the Reach 2 levees. In fact the original design did not account for the presence of the MRGO at all.

Utilizing the wave data discussed here Bea (2009) has estimated that "approximately $35 \%$ of the levees along the Reach 2 alignment were breached due to attack by waves, $47 \%$ were breached by a combination of wave attack and surge overtopping — backside erosion (including sheet pile repair breaches), and $18 \%$ were overtopped but did not breach (intact sheet pile repair sections, Dupre and Bienvenue navigation structures)."

\section{Summary and conclusions}

The MRGO channel increased conveyance into the city and created larger waves that destroyed many levee reaches early in the storm. These impacts, while apparently understood by USACE employees were never included in any design memorandums or analyses. Additionally, all analyses to date have missed the significance of channel widening on the energy of waves impacting the Reach 2 levees because they have underestimated both the potential for waves to reform in the channel and of the effects of wetland and foreshore erosion to increase the wave energy to which they were exposed during Katrina.

In January 2009 the USCAE started the process to seal the MRGO at the Bayou La Loutre ridge, a process that will take about a year.

Acknowledgements Professors Han Vrijling and Matthijs Kok, TU Delft, managed the SWAN and FINEL modeling and their help and expertise is gratefully acknowledged. This research was supported through the Team Louisiana effort by the Louisiana Department of Transportation and Development; by the Center for the Study of Public Health Impacts of Hurricanes, a Louisiana Board of Regents Health Excellence Fund Center, and by the McKnight Foundation. The MRGO Litigation team is thanked for funding the research performed by Delft University. Ahmet Binselam is thanked for assistance in data collection and analysis. 
Open Access This article is distributed under the terms of the Creative Commons Attribution Noncommercial License which permits any noncommercial use, distribution, and reproduction in any medium, provided the original author(s) and source are credited.

\section{References}

Bea, R. A. (2009). Expert Report. In re Katrina Canal Breaches Litigation, Civil Action No. 05-4182, US District Court for the Eastern District of Louisiana, Section "k" (2), Pertains to Robinson (06-2268)' Judge Duval. http://katrinadocs.com/report.cfm?r=12.

de Wit, L., Maaskant, B., Kok, M., \& Vrijling, J. K. (2008). Flow modeling new Orleans-Mississippi River Gulf Outlet, hurricane Katrina August 2005. Expert report In re Katrina Canal Breaches Litigation, Civil Action No. 05-4182, US District Court for the Eastern District of Louisiana, Section “k”(2), Pertaining to Robinson (06-2268)' Judge Duval. http://katrinadocs.com/report.cfm?r=49.

Fitzgerald, D., Penland, S., Milanes, A., Minor, M., Westphal, K., et al. (2008). Impact of the Mississippi River Gulf Outlet (MR-GO): Geology \& Geomorphology. In re Katrina Canal Breaches Litigation, Civil Action No. 05-4182, US District Court for the Eastern District of Louisiana, Section “k”(2), Pertaining to Robinson (06-2268)' Judge Duval. http://katrinadocs.com/report.cfm?r=45.http:// katrinadocs.com/report.cfm?r=59.

Gautier, C., Kok, M., \& Vrijling, J. K. (2008). Wave modeling New Orleans-Mississippi River Gulf Outlet, hurricane Katrina August 2005. Expert report. In re Katrina Canal Breaches Litigation, Civil Action No. 05-4182, US District Court for the Eastern District of Louisiana, Section “k”(2), Pertaining to Robinson (06-2268)' Judge Duval. (http://katrinadocs.com/report.cfm?r=50).

Shaffer, G. P., Day, J. W., Mack, S., Kemp, G. P., van Heerden, I., Poirrier, M. A., et al. (2009). The MRGO navigation project: a massive human-induced environmental, economic, and storm disaster. Journal of Coastal Research. In Press.

US Army Corps of Engineers. (1963). Technical Report No. 2-636; Effects on Lake Pontchartrain, LA of Hurricane Surge Control Structures and MRGO Channel-Hydraulic Model Investigation.

US Army Corps of Engineers. (1967). Lake Pontchartrain, LA and vicinity; Design Memorandum. No.1, Hydrology and Hydraulic Analysis; Part II- Barrier

US Corps of Engineers, New Orleans District. 1999. Habitat Impacts of the Construction of the MRGO, prepared for the Environmental Subcommittee of the Technical Committee convened by EPA in Response to St. Bernard Parish Council Resolution 12-98.

van Heerden, I. L. (2007). The failure of the New Orleans levee system following hurricane Katrina and the pathway forward. Public Administration review, Supp. to Vol. 67, Dec 2007.

van Heerden, I. L., \& Bryan, M. (2006). The storm - what went wrong and why during hurricane Katrina — the inside story from one Louisiana scientist (p. 308). New York: Publ Penguin/Viking.

van Heerden, I. L., Kemp, G. P., Mashriqui, H., Sharma, R., Prochaska, B., Capozzoli, L., et al. (2007). The failure of the New Orleans levee system during hurricane Katrina. A report prepared by TEAM LOUISIANA for Secretary Johnny Bradberry, Louisiana Department of Transport and Development, Baton Rouge, Louisiana.

Ivor van Heerden is an associate professor in the Department of Civil and Environmental Engineering at Louisiana State University, where he serves as director of the Hurricane Public Health Center. He has been the lead investigator on a pilot study assessing New Orleans hurricane vulnerability since 2002. Following Hurricane Katrina he headed an independent scientific investigation into the failures of the levee systems in southeast Louisiania and headed the state's official forensic levee investigation, known as Team Louisiana. In 2006 he published a book on his experience before and after Katrina, The storm: What went wrong and why during Hurricane Katrina- the inside story from one Louisiana scientist published by Penguin.

G. Paul Kemp is Vice-President for the Gulf Coast Initiative of the National Audubon Society. The National Audubon Society, a 100 year-old charitable non-profit organization devoted to saving nature. He also has responsibilities for management of one of the oldest privately held coastal wildlife sanctuaries in the U.S., the 26,000 acre Paul J. Rainey Sanctuary south of Intracoastal City on the west side of Vermilion Bay. Dr. Kemp is a former member of the LSU Hurricane Center and served on the Team Louisiana forensic investigation team. 
Robert Bea is professor in the Department of Civil and Environmental Engineering, Engineering and Project Management Group, University of California Berkeley and a member of the National Academy of Engineering, the Academy of Management, Life Member and Fellow of the American Society of Civil Engineers and a Fellow of the American Society of Mechanical Engineers. Bob is a registered professional engineer (civil, structural, geotechnical) in 8 states. His research and teaching have focused on risk assessment and management of engineered systems with specialization on human and organizational factors, criteria and guidelines for design and requalification, and margins of quality (factors of safety).

Gary P. Shaffer is a professor in the Department of Biological Sciences, Southeastern Louisiana University. Dr. Shaffer serves on the boards of a number of environmental organizations in Louisiana and has published extensively coastal freshwater forested wetlands. He is an academic advisor to the Coastal wetland Planning Protection and Restoration Act task force.

John W. Day, Jr. is Distinguished Professor Emeritus in the Department of Oceanography and Coastal Sciences, School of the Coast \& Environment at Louisiana State University, where he has taught since 1971. He has published extensively on the ecology and management of coastal and wetland systems and is co-author (with M. Kemp, C. Hall, and A. Yáñez-Arancibia) of Estuarine Ecology, coeditor (with C. Hall) of Ecological Modeling in Theory and Practice, coeditor (with W. Conner) of The Ecology of the Barataria Basin, An Estuarine Profile, and coeditor (with A. Yáñez-Arancibia) of the Ecology of Coastal Ecosystems in the Southern Mexico: The Terminos Lagoon Region.

Chad A. Morris is a Professional Land Surveyor Licensed in Louisiana \& Texas and has a B.S. in Surveying and Mapping, University of Florida. He presently is the owner of CMor Consulting, LLC. He serves on the ASTM E57 Committee - Working on Standards and Best Practices for the 3D Imaging (Laser Scanning) Industry and is a past president of the Louisiana Society of Professional Surveyors.

Duncan FitzGerald is a Professor of Earth Sciences at Boston University and an Adjunct Professor in the Earth and Environmental Sciences Department at the University of New Orleans. FitzGerald's interests are in shallow marine geology, extending from the coastal zone to the inner continental shelf. Recently, his group has begun several new projects that seek to quantify the effects of accelerated sea-level rise on backbarrier marshes and accompanying increases in tidal prism; wave-current interactions along Boston Harbor drumlins, transgressive processes along the Chandeleur Islands; storm-induced sediment transport on the inner shelf of the Merrimack Embayment; and analyzing sedimentary records containing evidence of climate change in Tijucas, Brazil.

Andrew Milanes is a vice president of Environmental Science Services, Inc. located in Denham Springs Louisiana. He has a BS Civil Engineering from LSU and is a certified Geographic Information Systems Professional (GISP) and Engineer Intern (EI). 